\title{
TingKaT KESIAPAN KOMPONEN WiSATA KREATIF JAYENGAN KAMPOENG PERMata BERDasarkan STAKEHOLDER
}

\author{
Lintang Praharyaning Suryono \\ PROGRAM STUdi PERENCANAAN WILAYAH DAN KotA \\ FAKULTAS TEKNIK \\ UNIVERSITAS SEBELAS MARET, SURAKARTA \\ WINNY ASTUTI \\ Program STUdi PERENCANAAN WILAYAH DAN KotA \\ FAKULTAS TEKNIK \\ UniVERsitas SEbelas Maret, SuraKarta \\ MURTANTI JANi RAHAYU \\ Program StUdi PERENCANAAN WiLAYAH DAN KotA \\ FAKULTAS TEKNIK \\ Universitas SEbelas Maret, SuraKarta
}

\begin{abstract}
Jayengan Kampoeng Permata is a village ofgem merchant Banjar community which is now being planned to become a creative tourism destination. This study aims to determine how the level of readiness of creative tourism components Jayengan Kampoeng Permata by stakeholders. This study uses a deductivequantitative method. The sampling technique used purposive sampling with JKP'sstakeholders as the interviewees. JKP's readiness level was somewhat prepared. Components that contributed the highest value to lowest for readiness of JKP are creative tourism community, infrastructure, attractiveness, external institutions, tourists and internal institutional. The results showed that the readiness of people not guarantee readiness Jayengan Kampoeng Permata as a creative tourism destination, fascination owned Jayengan Kampoeng Permata has not been able to invite tourists, the readiness of JKP's infrastructure sufficient not been able to attract tourists, internal institutional role in supporting preparedness Jayengan Kampoeng Permata and external institutions as external factors readiness $J K P$.
\end{abstract}

Keywords: Radiness, Tourism Components, Creative Tourism.

\section{PENDAHULUAN}

Pariwisata adalah gejala yang ditimbukan dari perjalanan orang asing serta penyediaan tempat tinggal sementara, yang tidak ada hubungannya dengan pencarian nafkah (Yoeti dalam Arjana 2015, 6). Sebuah destinasi wisata hendaknya memenuhi beberapa komponen yang terdiri dari daya tarik, sarana prasarana wisata, kelembagaan, wisatawan serta masyarakat.

Dalam penyelenggaran pariwisata perlu melibatkan stakeholder agar kegiatan kepariwisataan dapat berlangsung dengan baik. Stakeholder merupakan individuindividuatau kelompok-kelompok yang ahli dalambidangnya dan mempunyai peran di dalam suatukebijakan yang menaungi bidangnya tersebut. Stakeholderpariwisata tidak hanya berperan dalammengambil keputusan bersama untuk kebijakanpengembangan pariwisata, namun juga berperandalam mengelola wisata.

Wisata kreatif menurut International Conference on Creative Tourism tahun 2008, adalah perjalanan menuju ke tempat yang memiliki pengalaman asli dan menarik (hati/perasaan) dengan cara berpartisipasi dalam belajar seni, budaya, atau karakter spesial dari sebuah tempat, serta menyediakan hubungan/ interaksi dengan penduduk yang tinggal dan membentuk budaya kehidupannya. Wisata kreatif 
berdasarkan pada experiencing, participating dan learning. Wisata kreatif tidak bisa terpuaskan dengan melihat-lihat saja, tetapi dapat dipenuhi dengan partisipasi aktif wisatawannya. (Ohridska-Olson, 2010).

Terdapat salah satu destinasi wisata kreatif di Kota Surakarta, tepatnya berada di Kelurahan Jayengan bernama Jayengan Kampoeng Permata (JKP).Sebagai sebuah destinasi wisata, Jayengan Kampoeng Permata (JKP) masih berada pada tahap awal penciptaan wisata kreatif. Pada tahapan ini, JKP sudah memenuhi beberapa komponen penting wisata kreatif. Komponen yang telah dipenuhi adalah memiliki daya tarik industri kreatif berupa pengolahan permata dan kuliner; memiliki keberagaman budaya lokal sebagai atraksi; memiliki beberapa sarana prasarana wisata kreatif seperti sarana akomodasi, sarana transportasi, dan prasarana yang lengkap (listrik, air bersih, komunikasi); serta memiliki forum JKP sebagai pengelola wisata. JKP berada pada lokasi strategis pengembangan pariwisata berbasis industri kreatif di Kota Surakarta. Selain itu, JKP juga mendapat dukungan penuh dari pemerintah dalam pelaksanaannya menjadi destinasi wisata kreatif.

Namun, sebagai wisata baru masih terdapat beberapa kekurangan dari komponen-komponen yang belum tertangani dengan baik. Daya tarik yang belum terintegrasi, atmosfer kawasan wisata yang tidak kuat, menjadi masalah yang masih dimiliki daya tarik JKP. Masalah internal pengelola yang belum selesai juga menghambat pengelola melakukan perannya. Rendahnya partisipasi masyarakat yang seharusnya menjadi tonggak penyelenggaraan wisata kawasan juga belum terselesaikan. Pengrajin yang mulai pergi juga mengancam keberlangsungan wisata JKP ini.

Berdasarkan kondisi-kondisi dari komponen wisata JKP tersebut, melalui penelitian ini akan dilihat bagaimana tingkat kesiapan komponen wisata kreatif Jayengan Kampoeng Permata berdasarkan stakeholder.

\section{METODE PENELITIAN}

Pendekatan yang akan digunakan dalam penelitian ini adalah pendekatan deduktif kuantitatif. Pendekatan deduktif menjadikan teori sebagai acuan dalam penelitian yang dilakukan. Penelitian kuantitatif harus menentukan unsur yang terkait dengan tujuan, pendekatan, subjek, sampel dan sumber data secara jelas, rinci, dan mantap sebelum penelitian dilakukan.

Pemilihan sampel menggunakan teknik purposive sampling. Sampel yang digunakan dalam penelitian ini adalah pakar yang termasuk stakeholder triple helix dalam penyelenggaraan wisata kreatif JKP.

Penelitian yang dilakukan menggunakan tiga analisis yakni analisis kesiapan komponen wisata kreatif JKP menggunakan skoring, analisis evaluatif penentuan kriteria kesiapan destinasi wisata kreatif JKP menggunakan Analytic Hierarchy Process (AHP), serta analisis tingkat kesiapan JKPyang dilakukan dengan subtitusi.

\section{HASIL DAN PEMBAHASAN}

Analisis kondisi kesiapan komponen wisata JKP berdasarkan pakar menunjukkan komponen sarana prasarana memiliki nilai rata-rata kesiapan paling tinggi $(3,85)$. Kesiapan paling rendah adalah komponen kelembagaan internal $(1,89)$. Rata-rata untuk komponen lainnya yaitu kelembagaan eksternal 3,29; masyarakat 3,11; daya tarik wisata 2,6; dan wisatawan 2,00.

Tabel 1. Kesiapan Komponen Wisata Kreatif JKP

\begin{tabular}{|c|l|r|l|}
\hline No & \multicolumn{1}{|c|}{ Komponen } & $\begin{array}{c}\text { Tata-rata } \\
\text { Komponen }\end{array}$ & $\begin{array}{c}\text { Tingkat } \\
\text { Kesiapan } \\
\text { Komponen }\end{array}$ \\
\hline 1 & $\begin{array}{l}\text { Daya tarik wisata } \\
\text { kreatif }\end{array}$ & 2,60 & Agak siap \\
\hline 2 & Sarana prasarana & 3,85 & Cukup siap \\
\hline 3 & $\begin{array}{l}\text { Kelembagaan internal } \\
\text { wisata kreatif }\end{array}$ & 1,89 & Tidak siap \\
\hline 4 & $\begin{array}{l}\text { Masyarakat wisata } \\
\text { kreatif }\end{array}$ & 2,11 & Cukup siap \\
\hline 5 & Wisatawan & 3,29 & Cidak siap \\
\hline 6 & $\begin{array}{l}\text { Kelembagaan eksternal } \\
\text { wisata kreatif }\end{array}$ \\
\hline
\end{tabular}

Sumber: Analisis Penulis, 2016

Analisis evaluatif penentuan kriteria kesiapan destinasi wisata kreatif JKP menunjukkan bahwa masyarakat wisata merupakan kriteria peringkat kepentingan 
teratas dengan bobot nilai 0,341 dan lembaga eksternal adalah kriteria peringkat terendah dengan nilai 0,068 . Berikut adalah tabel rangking pembobotan kriteria komponen:

Tabel 2. Rangking Pembobotan Kriteria Komponen

\begin{tabular}{|l|l|r|}
\hline No & \multicolumn{1}{|c|}{ Komponen } & $\begin{array}{c}\text { Bobot } \\
\text { Komponen }\end{array}$ \\
\hline 1 & Daya tarik wisata kreatif & 0,253 \\
\hline 2 & Sarana prasarana & 0,199 \\
\hline 3 & Kelembagaan internal wisata kreatif & 0,069 \\
\hline 4 & Masyarakat wisata kreatif & 0,341 \\
\hline 5 & Wisatawan & 0,071 \\
\hline 6 & Kelembagaan eksternal wisata kreatif & 0,068 \\
\hline
\end{tabular}

Sumber: Analisis Penulis, 2016

Analisis tingkat kesiapan JKP menunjukkan nilai kesiapan Jayengan Kampoeng Permata adalah sebesar 2,98 yang berada pada tingkat 3 atau dengan kata lain tingkat kesiapan JKP adalah Agak Siap.

Nilai kesiapan JKPdidapatkan melalui penyelesaian persamaan:

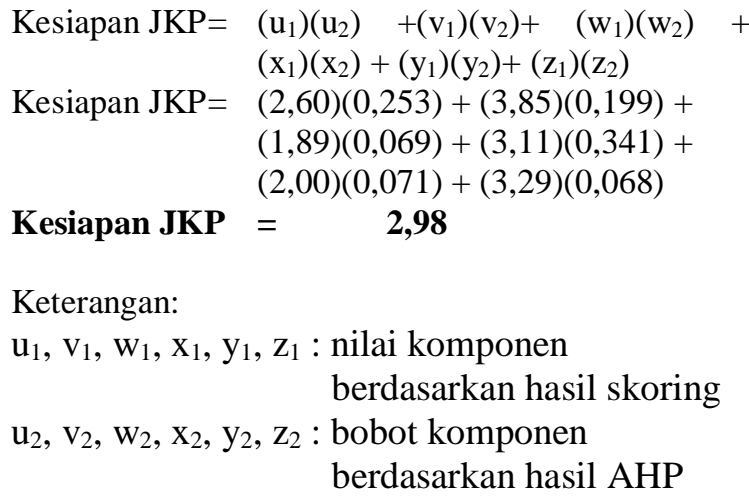

Keterangan:

$\mathrm{u}_{1}, \mathrm{v}_{1}, \mathrm{w}_{1}, \mathrm{x}_{1}, \mathrm{y}_{1}, \mathrm{z}_{1}$ : nilai komponen berdasarkan hasil skoring

$\mathrm{u}_{2}, \mathrm{v}_{2}, \mathrm{w}_{2}, \mathrm{x}_{2}, \mathrm{y}_{2}, \mathrm{z}_{2}$ : bobot komponen berdasarkan hasil AHP

Berikut adalah tabel tingkat kesiapan Jayengan Kampoeng Permata:

Tabel 3. Tingkat Kesiapan Jayengan Kampoeng

Permata

\begin{tabular}{|l|l|c|c|c|}
\hline No & \multicolumn{1}{|c|}{ Komponen } & Nilai & $\begin{array}{c}\text { Nilai } \\
\text { Kesiapan } \\
\text { JKP }\end{array}$ & $\begin{array}{c}\text { Tingkat } \\
\text { Kesiapan } \\
\text { JKP }\end{array}$ \\
\hline 1 & Daya tarik wisata kreatif & 0,658 & & \\
\hline 2 & Sarana prasarana & 0,766 & \multirow{2}{*}{2,98} & \multirow{2}{*}{ Agak siap } \\
\hline 3 & $\begin{array}{l}\text { Kelembagaan internal } \\
\text { wisata kreatif }\end{array}$ & 0,130 & & \\
\cline { 1 - 2 } 4 & $\begin{array}{l}\text { Masyarakat wisata } \\
\text { kreatif }\end{array}$ & 1,061 & & \\
\hline 5 & Wisatawan & 0,142 & \\
\cline { 1 - 2 } 6 & $\begin{array}{l}\text { Kelembagaan eksternal } \\
\text { wisata kreatif }\end{array}$ & 0,224 & & \\
\hline
\end{tabular}

Sumber: Analisis Penulis, 2016

Kesiapan Jayengan Kampoeng

Permata berdasarkan stakeholder masih berada pada tingkat agak siap karena komponen-komponennya pun masih belum siap. Komponen yang menyumbang nilai tertinggi bagi kesiapan JKP adalah masyarakat wisata kreatif $(1,061)$, serta terendah adalah kelembagaan internal $(0,130)$. Peringkat kedua hingga kelima berturut-turut adalah sarana prasarana $(0,766)$, daya tarik $(0,658)$, kelembagaan eksternal $(0,224)$ serta wisatawan $(0,142)$.

Sebagai sebuah sistem pariwisata, komponen-komponen ini berhubungan saling mempengaruhi satu sama lain. Pengaruh yang timbul antar komponen wisata kreatif adalah sebagai berikut:

1. Kesiapan Masyarakat Wisata Belum Menjamin Kesiapan Jayengan Kampoeng Permata sebagai Destinasi Wisata Kreatif

Masyarakat wisata kreatif JKP merupakan komponen wisata kreatif dengan kesiapan tertinggi. Namun, kesiapan masyarakat wisata kreatif JKP ternyata belum mampu menjamin kesiapan JKP secara keseluruhan. Cukup siapnya masyarakat wisata JKP belum mampu membuat JKP menjadi siap atau bahkan cukup siap.

Masyarakat/ sumber daya manusia kreatif menjadi faktor esensial dalam penyelenggaraan pariwisata. Hal ini sesuai dengan pendapat Suwantoro $(1997,19)$ serta hasil analisis proses hirarki (AHP) dalam penelitian ini. Masyarakat wisata mampu mempengaruhi berbagai komponen wisata kreatif. Masyarakat wisata yang memiliki kreatifitas tinggi akan mampu mengelola potensi yang dimiliki (sumberdaya, daya tarik, sarana prasarana) menjadi lebih menarik untuk dikunjungi (Pitana dan Diarta, 2009), dan mendukung padakeberkelanjutan penyelenggaraan tempat wisata (Suwantoro 1997,23).

Masyarakat yang kreatif dan spesifik biasanya mengklaster menjadi komunitas tersendiri karena keragaman dan inovasi yang tinggi. Kegiatan yang membentuk klaster ini mampu membentuk atmosfer kawasan karena kegiatannya yang khas dan dapat menjadi pembeda dari tempat-tempat lainnya (Hengky Hermantoro, 2013). Pengarajin serta pedangang JKP yang bekerja pada sektor industri kreatif jumlahnya tidak sampai $40 \%$ proporsi penduduk sehingga tidak mampu 
mendominasi kegiatan khas di kawasan. Ketidakmampuan kegiatan industri kreatif untuk mendominasi kegiatan kawasan menyebabkan atmosfer khas wisata JKP tidak kuat. Faktor jumlah sumberdaya manusia kreatif merupakan salah satu penyebab masyarakat wisata JKP yang cukup siap namun tidak dapat membuat wisata JKP menjadi siap atau bahkan cukup siap.

Kemampuan pelayanan serta keramahan berdampak langsung pada kepuasan pengunjung sebuah destinasi wisata (Suwantoro 1997,19) Semakin baik keramahan dan pelayanan yang diberikan, maka kepuasan pengunjung akan kualitas sebuah destinasi wisata kreatif akan semakin baik. Namun, studi yang dilakukan terhadap JKP tidak menunjukkan hal yang serupa/ tidak sesuai dengan pendapat tersebut. Kemampuan pelayanan serta keramahan JKP memiliki nilai tinggi (kategori siap) sedangan kepuasan terhadap kualitas daya tarik JKP agak rendah (kategori agak siap). Perbedaan ini dikarenakan kepuasan terhadap kualitas daya tarik JKP tidak hanya dipengaruhi kemampuan pelayanan serta keramahan. Stakeholder menilai daya tarik yang dimiliki JKP belum memiliki keragaman pilihan berpartisipasi yang cukup sehingga hal ini yang membuat penilaian kepuasan kualitas wisata JKP agak baik.

\section{Daya Tarik yang dimiliki Jayengan Kampoeng Permata Belum Mampu Mengundang Wisatawan}

Daya tarik merupakan faktor penarik dari kunjungan wisatawan. Daya tarik yang dikelola secara profesional/ baik dapat menarik wisatawan untuk datang (Suwantoro 1997,19). Wisata kreatif menawarkan daya tarik berupa kesempatan untuk mengembangkan kreativitas konsumen melalui partisipasi aktif dalam pengalaman pelatihan dan pembelajaran mengenai karakteristik tempat tujuan liburan serta memahami kehidupan dan budaya lokal bersama penduduk setempat. (Richard and Wilson, 2007). Sebagai sebuah destinasi wisata kreatif, JKP memiliki satu showroom permata, satu showroom perak, dan beberapa tempat makan yang menyediakan atraksi proses pembuatan produknya.
Namun sayangnya, JKP belum memiliki atraksi berupa pengalaman dan pembelajaran untuk membuat permata maupun kuliner yang ada. Sehingga, sesuai dengan pendapat Suwantoro tersebut, daya tarik wisata kreatif JKP yang belum maksimal ternyata mempengaruhi jumlah kunjungan wisatawan yang belum bertambah hingga saat ini.

Menurut King (2009) ragam pilihan berpartisipasi serta keunikan merupakan penawaran daya tarik yang diharapkan wisatawan untuk dipenuhi, dan akhirnya juga akan mempengaruhi keinginan wisatawan untuk datang. Sehingga, ragam pilihan yang sedikit di JKP ternyata juga mempengaruhi jumlah wisatwan yang tetap sedikit dan tidak kunjung bertambah. Berbeda dengan pendapat King (2009), daya tarik unik yang dimiliki JKP seharusnya dapat membantu meningkatkan jumlah kunjungan wisatawan. Namun, keunikan daya tarik JKP belum banyak diketahui oleh orang-orang. Keunikan yang dimiliki JKP adalah dari cara pengolahan perhiasan maupun kuliner khas Jayengan yang tradisional serta kebudayaan membagikan Bubur Samin setiap hari saat menjelang berbuka puasa di Bulan Ramadhan.

Atmosfer wisata kreatif dipengaruhi oleh aktivitas masyarakat serta arsitektural kawasan. Atmosfer wisata yang baik membuat orang mudah mengingat, mengenali dan memiliki impresi yang bagus terhadap sebuah destinasi wisata (Hengky Hermanto, 2011). Seperti yang telah dibahas pada bab sebelumnya, ternyata sesuai dengan pendapat ini, kegiatan industri kreatif yang tidak mampu mendominasi membuat atmosfer wisata menjaddi lemah. Lemahnya atmosfer wisata JKP membuat daya tarik wisatanya tidak mudah dikenali sehingga, sekali lagi, hal ini mempengaruhi jumlah kunjungan wisatwan.

Pariwisata terbentuk dari hubungan yang terintegrasi antar komponen. Apabila satu komponen tidak berfungsi dengan baik, maka keseluruhan sistem juga tidak akan berjalan dengan baik. (Pitana dan Diarta 2009, 57). Sesuai dengan pendapat ini, tidak siapnya Jayengan Kampoeng Permata ternyata disebabkan karena integrasi/ 
hubungan daya tariknya rendah. Integrasi yang rendah ini dikarenakan peran dari kelembagaan internal JKP belum tuntas, yakni pengorganisasian yang masih lemah dari Forum JKP serta pembuatan paket wisata oleh tour operator yang belum tuntas dikarenakan ketiadaan tour operator bagi JKP.

\section{Kesiapan Sarana Prasarana JKP yang Cukup Memadai Belum Mampu Menarik Wisatawan}

Sarana prasarana wisata juga menjadi faktor penarik kunjungan wisatawan. Apabila pelayanan sarana prasarana ini baik maka akan menarik wisatawan untuk datang berkunjung (Suwantoro 1997, 21-22). Namun, hal ini tidak sesuai dengan yang terjadi di Jayengan Kampoeng Permata. JKP memiliki sarana yang cukup lengkap namun jumlah kujungan belum juga meningkat setelah launching. Hal ini disebabkan karena sebelum dan sesudah launching, sarana yang ada masih tetap sama jumlah, bentuk maupun pengelolaannya.

Penelitian yang dilakukan Gretzel, et al., dalam Subiyantoro menyatakan bahwa pelayanan personal pariwisata (seperti akomodasi serta transportasi) merupakan salah satu kunci untuk meningkatkan volume jumlah wisatawan ke suatu daerah. Ketersediaan akomodasi sebagai sarana untuk tinggal sementara membuat kunjungan lebih nyaman karena wisatawan tidak akan mengalami kebingungan bagaimana dan dimana mereka akan menghabiskan waktu saat tidak ada destinasi yang bisa mereka tuju. Akses transportasi dapat meningkatkan perkembangan wisata serta peningkatan jumlah wisatawan karena akses menjadi semakin lancar dan biaya yang ditimbulkan semakin murah. Berseberangan dengan pendapat tersebut, sarana akomodasi dan transportasi JKP yang cukup tersedia ternyata tidak mampu membuat volume kunjungan wisatawan tinggi.

Dari penelitian yang dilakukan, tetap sedikitnya jumlah kunjungan disebabkan karena sarana workshop dan sarana kebudayaan sebagai wadah dari atraksi utama yang ditawarkan tidak tersedia dengan baik. Sarana workshop masih berupa bengkel pengolahan perhiasan serta dapur yang belum bisa mewadahi kegiatan pembelajaran dalam pembuatan perhiasan serta kuliner khas JKP. Meskipun tidak mempengaruhi secara langsung sarana prasarana yang baik dapat meningkatkan nilai atraksi/ daya tarik wisata yang kemudian dapat mempengaruhi minat wisatawan untuk berkunjung (Soebiyantoro,-). Sesuai dengan pendapat ini, sarana workshop dan sarana kebudayaan yang tidak siap membuat daya tarik wisata kreatif dan keberagaman kebudayaan lokal tidak siap pula. Tidak siapnya daya tarik utama JKP ini menyebabkan rendahnya jumlah kunjungan wisatawan domestik maupun mancanegara.

\section{Kelembagaan Internal Berperan dalam Mendukung Kesiapan Jayengan Kampoeng Permata}

Kelembagaan internal wisata kreatif terdiri dari pengelola wisata serta tour operator (Suwantoro, 1997). Diantara semua komponen, kelembagaan internal JKP memiliki kesiapan yang paling rendah dengan tingkat tidak siap. Tidak siapnya kelembagaan disebabkan oleh beberapa hal yakni lemahnya peran koordinasi pengelola wisata dan tidak adanya tour operator yang membuat tidak adanya paket wisata bagi JKP.

Pengelola wisata merupakan faktor penting yang akan mengelola komponenkomponen pariwisata, untuk memastikan semuanya bersinergi dalam menciptakan sebuah destinasi wisata yang mampu menarik minat wisatawan untuk datang mengunjunginya. Dalam pengelolaan pariwisata diperlukan kesamaan visi antar anggota. Kesamaan visi dapat memunculkan aspirasi dan pada akhirnya dapat meningkatkan tingkat partisipasi pengelola wisata maupun masyarakat setempat. Kesamaan visi ini akan tercapai apabila anggota telah bersatu dan terorganisir. Usaha penyamaan visi serta faktor kepemimpinan dibutuhkan untuk menunjang koordinasi antar semua pihak (Asker et al, 2010).

Lemahnya peran koordinasi pengelola wisata JKP menimbulkan tidak terintegrasinya daya tarik JKP hingga 
rendahnya

masyarakat.Keengganan

partisipasi

pengurus untuk berperan aktif dalam memajukan JKPmenjadi masalah yang menghambat Forum JKP untuk menuntaskan peran pengkoordinasian terhadap daya tarik, sarana, maupun pihakpihak yang terkait (publik maupun swasta) serta strategi marketing. Keenganan untuk berperan aktif juga menyebabkan pengurusnya kurang memahami tentang pengembangan JKP secara keseluruhan dan menimbulkan perbedaan pandangan. Dengan adanya masalah ini, Forum JKP selaku pengelola sekarang sedang melakukan pengguatan internal untuk meningkatkan persatuan antar anggota agar kesamaan visi misi dapat teraih. Sesuai dengan pendapat Asker et al(2010) untuk meningkatkan partisipasi, Forum JKP melakukan penyamaan visi. Peran dari pimpinan Forum JKP sangat dibutuhkan untuk menciptakan pengelola wisata yang memiliki kesamaan visi, sehingga semua pengurus dapat menyalurkan aspirasi dan bekerja dengan baik sehingga peran koordinasi pengelola wisata dapat tuntas.

Telah disebutkan sebelumnya bahwa lemahnya peran koordinasi pengelola wisata dapat berdampak pada rendahnya partisipasi. Hal ini sesuai dengan yang terjadi di JKP, belum tuntasnya peran koordinasi Forum JKP menyebabkan rendahnya partisipasi masyarakat setempat. Masyarakat JKP belum sepenuhnya berpartipasi dalam penyelenggaraan wisata. Rendahnya partisipasi masyarakat ini dikarenakan tidak adanya sosialisasi serta koordinasi dari pihak pengelola, sehingga masyarakat yang berpartisipasi hanya sebagian kecil dan lainnya acuh. Partisipasi masyarakat sebenarnya adalah tonggak dalam pelestarian dan keberlanjutan lingkungan wisata karena masyarakatlah bersinggungan langsung dengan tempat wisata. Partisipasi yang baik akan membuat lingkungan kawasan wisata lebih berkelanjutan dan lebih memiliki daya saing untuk dikunjungi. (Suwantoro, 1997). Partisipasi masyarakat dapat mendorong pemanfaatan berkelanjutan dan perlindungan terhadap sumber daya alam yang sensitif, menghindari eksploitasi dan ketergantungan terhadap satu sumber daya, mendukung pemanfaatan sumber daya alam secara tidak konsumtif, meningkatkan kesadaran terhadap lingkungan di tingkat nasional dan lokal, serta meningkatkan pemahaman terhadap hubungan antara lingkungan dan pembangunan ekonomi yang berkelanjutan. (Tasci et al, 2013).

Tidak adanya tour operator mengakibatkan peran penyusunan, penyediaan dan pemasaran paket wisata tidak dapat dilakukan. Hal ini mengakibatkan atraksi wisata kreatif yang ada berdiri sendiri-sendiri tanpa ada kesatuan. Pengunjung wisata JKP hanya akan mengunjungi atraksi wisata yang mereka ketahui, padahal JKP memiliki beberapa atraksi wisata yang dapat dinikmati.

\section{Kelembagaan Eksternal sebagai Faktor Eksternal Kesiapan JKP}

Kelembagaan eksternal terdiri dari pemerintah serta pemasaran. Kelembagaan eksternal wisata kreatif JKP berada pada tingkat cukup siap. Pemerintah Kota Surakarta melalui SKPD terkait, saat ini telah mencoba memasukkan pengembangan JKP dalam program kerjanya. Pemasaran yang dilakukan saat ini telah sampai pada skala nasional, sehingga lebih luas orangorang untuk dapat mengetahui keberadaan JKP.

Dalam penyelenggaraan pariwisata, dukungan dari berbagai pemangku kepentingan khususnya pemerintah sangat diperlukan. Dukungan tersebut akan dapat terwujud apabila ada usaha untuk senantiasa berkoordinasi dengan pemerintah sehingga tercipta sinergi yang baik. Pernyataan tersebut sepertinya kurang sesuai dengan kenyataan yang terjadi di JKP. Peran koordinasi JKP masih belum cukup baik namun dukungan yang diberikan oleh pemerintah Kota Surakarta sudah maksimal. Belum diketahui alasan dari terjadinya fenomena ini.

\section{KESIMPULAN}

Tingkat kesiapan JKP berdasarkan stakeholder adalah agak siap. Agak siapnya JKP ini dikarenakan semua komponen wisata kreatifnya tidak ada yang berada pada 
tingkat siap (belum benar-benar tuntas, cukup, terpenuhi). Berdasarkan stakeholder, sarana prasarana wisata kreatif, masyarakat wisata kreatif, dan kelembagaan eksternal wisata kreatif berada pada tingkat cukup siap; daya tarik wisata kreatif agak siap; serta kelembagan internal wisata kreatif dan wisatawan JKP tidak siap. Perbaikan di semua komponen perlu dilakukan untuk membuat JKP menjadi siap menjadi destinasi wisata kreatif.

Komponen sarana prasarana JKP adalah komponen dengan kesiapan paling tinggi dalam kategori cukup siap. JKP memiliki prasarana (listrik, air, komunikasi) yang tersedia dan dapat menjangkau seluruh wilayah. JKP memiliki hotel di dalam kawasan JKP (sebelah utara lapangan Kartopuran) dan beberapa sarana akomodasi lainnya di sekitar JKP yang membuat orang merasa sarana akomodasi mencukupi dan mampu melayani kebutuhan jika ingin menginap. Transportasi yang melayani Kawasan JKP baik internal maupun eksternal juga sudah ada. Untuk transpotasi internal dapat dilakukan dengan menggunakan kendaraan pribadi (motor dan mobil), becak, serta taksi. Untuk wisatawan dapat menjangkau JKP dari Bandara, Stasiun Purwosari, Stasiun Solo Balapan dilanjutkan dengan taksi, bus, atau angkutan kota.Sarana workshop JKP terletak di showroom Jusuf Jewelery, showroom Nisrina serta dapur Srabi Notosuman. Namun, pada sarana ini wisatawan tidak bisa berpartisipasi dan belajar membuat perhiasan ataupun kuliner dan masih sekedar melihat saja.

Masyarakat wisata kreatif JKP juga memiliki kesiapan yang cukup. JKP memiliki etnis yang beragam yakni Banjar, Jawa, Cina yang diistilahkan dengan "Jarwana". Masyarakat JKP pun memiliki keramahan serta kemampuan pelayanan yang baik. Keramahan oleh penduduk tergambar dari para penjual yang menyapa pengunjung/ pembeli terlebih dahulu ketika sampai di tempat mereka berdagang. Kemampuan pelayanan dapat digambarkan dari cekatannya para staff/ pedagang melayani pembeli. Namun, kontribusi tenaga kerja industri kreatif JKP dinilai masih lemah karena belum mencapai $40 \%$ serta partisipasi dari masyarakat dinilai rendah. Rendahnya partisipasi dikarenakan belum adanya sosialisasi terkait perencanaan Kawasan Jayengan Kampoeng Permata ke masyarakat sekitar.

Sebagai sebuah destinasi wisata, tentunya tidak bisa terlepas dari dukungan kelembagaan eksternalnya. Kelembagaan eksternal yang terkait dengan JKP adalah BAPPEDA Kota Surakarta, Dinas Kebudayaan dan Pariwisata, Dinas Perindustrian dan Perdagangan serta Kelurahan Jayengan. Kelembagaan eksternal JKP dinilai cukup siap karena sudah hampir tuntas menjalankan peranperannya. Kelembagaan-kelembagaan tersebut telah memasukkan program pengembangan bagi JKP kedalam rencana stretegis kelembagaannya (meskipun belum disahkan karena proses administrasi penganggaran di tingkat Kota). Pemasaran juga merupakan bagian dari kelembagaan eksternal. Pemasaran yang dilakukan JKP telah sampai pada skala nasional. Kegiatan pemasaran yang dilakukan JKP adalah melalui pameran tingkat nasional, liputan media masa daerah maupun nasional.

Berdasarkan penelitian yang dilakukan, daya tarik JKP dinilai berada pada tingkat agak siap. Hal ini dikarenakan industri kreatif, keberagaman budaya lokal, atmosfer wisata kreatif, serta integrasi daya tarik sebagai aspek dari komponen daya tarik wisata kreatif JKP agak siap pula. Industri kreatif dan keberagaman budaya lokal diketahui tidak memiliki ragam pilihan berpartisipasi yang bervariasi. Atmosfernya lemah karena kegiatan pengolahan perhiasan, kuliner dan kebudayaan kurang mendominasi pada kegiatan sehari-hari maupun pada penggunaan lahannya. Integrasi daya tarik yang kurang baik karena tidak ada pengorganisasian antar daya tarik yang menjadikannya kesatuan paket wisata.

Komponen wisatawan JKP memiliki kesiapan yang rendah. Setelah launching JKP, jumlah pengunjung belum juga bertambah. Wisatawan merupakan pasar pariwisata. Apabila jumlah pengunjung tidak berubah, wisata kreatif JKP akan tetap seperti saat ini/ tidak akan berkembang. 
Diantara semua komponen, kelembagaan internal memiliki kesiapan yang paling rendah. Hasil studi menunjukkan komponen kelembagaan internal wisata kreatif JKP berada pada tingkat tidak siap. Forum JKP selaku pengelola wisata dinggap hampir tuntas melaksanakan program promosi karena sudah melakukan promosi dalam bentuk cetak, elektronik dan pameran. Namun, perannya untuk melakukan strategi marketing dan pengorganisasian sektor umum dan swasta dirasa masih kurang tuntas. Keengganan kebanyakan pengurus untuk berperan aktif dalam memajukan JKP menjadi masalah yang belum terpecahkan saat ini. Kondisi inilah yang saat ini sedang menjadi perhatian Forum JKP untuk segera diselesaikan melalui penguatan internal. Selain itu, tidak adanya tour operator mengakibatkan peran penyusunan, penyediaan dan pemasaran paket wisata tidak dapat dilakukan.

\section{DAFTAR PUSTAKA}

\section{Buku}

Arjana, I $\quad$ Gusti. 2015. GeografiPariwisatadanEkonomiKreatif . Depok: Rajawali Press.

DPU. 2011. KamusPenataanRuang. Jakarta Hermanto, Hengky. 2011. Creative-Based Tourism dari Wisata Rekreatif menuju Wisata Kreatif. Depok: Aditri

Page, Stephen. 1995. Urban Tourism. London: Routledge.

Richards, G., and Julie Wilson. 2007. Tourism, Creativity and Development. London: Routledge

Richards, G., and Raymond, C. (2000). Creative Tourism. London: ATLAS

Yoeti, Oka A. 1994. Pengantar Ilmu Pariwisata. Bandung: Penerbit Angkasa

\section{Paper dan Artikel}

European Commission. 2002. Using Natural and Cultural Hritage to Develop Sustainable Tourism In NonTraditional Tourist Destinations. Europe: Directorate General Enterprise.

Greg Richards. 2009.Tourism development trajectories- From culture to creativity?. London: Routledge
Nawawi, Ramli. 2007. Kongres Budaya Banjar. Surakarta: Universitas Muhammadiyah Surakarta.

Piboonrungroj, Pairach, and Korawan Sangkakorn. 2013. Tourism Logistics Management: A Case Of Cultural Creative Tourism In Thailand. Bangkok.

Ohridska-Olson, R. 2010. The Creative Tourism Business Model. Cultural Realms: Vizantia Enterprises

Ohridska-Olson, Rossitza., and Ivanov Stanislav. 2011. Creative Tourism Business Model And Its Application In Bulgaria. Bulgaria: Vizantia Enterprises.

UNESCO. 2006. Towards Sustainable Strategies for Creative Tourism Discussion Report of the Planning Meeting for 2008 International Conference on Creative Tourism. New Mexico: UNESCO.

\section{Penelitian}

Astuti, et al. 2015. Grand Design Pengembangan "Kampung Wisata Industri Jayengan" Sebagai Upaya Percepatan Ekonomi Kawasan Berbasis Lokalitas. Surakarta

Pratiwi, Alfariani. 2015. Tingkat KesiapanKota Surakarta TerhadapDimensiMobilitasCerdasSeba gaiBagian Dari Konsep Kota Cerdas. Surakarta: UNS Library.

Ramadhani, Amesta Kartika. 2015. Kajian Kesiapan Penerapan Konsep Kota Kreatif Desain di Surakarta. Surakarta: UNS Library.

Setywan, Arif Budi. 2013. Pengembangan Kota Solo Sebagai Kota Wisata Kreatif. Surakarta: UNS Library.

\section{Jurnal}

Maulana, Sidiq., dan Nurini. 2010. Jurnal Tata Loka Vol.12 No.4 Kajian Kesiapan Kampoeng Batik Laweyan Solo Sebagai Kawasan Wisata Budaya. Semarang: Biro Penerbit Planologi UNDIP.

\section{Peraturan Pemerintah}

Pemda Kota Surakarta. 2011. Buku Rencana Detail Tata Ruang Kawasan I Kota Surakarta. Surakarta (bukan naskah publikasi). 
Peraturan Mentri Pekerjaan Umum Nomor 20 Tahun 2011 tentang Pedoman Penyusunan Rencana Detail Tata Ruang dan Peraturan Zonasi Kabupaten/Kota.

Web
http://careernews.id/issues/view/2577-JadiApa-Itu-Industri-Kreatif 14 Desember 2015 pukul 16:29

http://jogja.in/14-sub-sektor-industrikreatif-di-indonesia/\#.Vm6Nx-KvOQw 14 Desember 2015 17:13 